The hegemon's choice between power and security: explaining US policy toward Asia after the Cold War

He, Kai

Published in:

Review of International Studies

DOI:

10.1017/S0260210510000227

Publication date:

2010

Document version

Early version, also known as pre-print

Citation for published version (APA):

$\mathrm{He}, \mathrm{K}$. (2010). The hegemon's choice between power and security: explaining US policy toward Asia after the Cold War. Review of International Studies, 36(4), 1121-1143. https://doi.org/10.1017/S0260210510000227 


\title{
The hegemon's choice between power and security: explaining US policy toward Asia after the Cold War
}

\author{
KAI HE*
}

\begin{abstract}
After the Cold War, US strategists have suggested four strategies for the hegemon: hegemonic dominion, selective engagement, offshore balancing, and multilateralism. Rather than debating which strategy is the best for the US at all times, this article focuses on examining which policy is more likely to be chosen by the hegemon - the US - under different strategic conditions. Through a neoclassical realist argument - the powerperception hegemonic model, I argue that US foreign policy depends on how US policymakers perceive US hegemonic status in the international system. Under rising and stable hegemony, selective engagement and hegemonic dominion are two possible powermaximisation strategies given the weak security constraints from the system. Under declining hegemony, offshore balancing and multilateralism are more likely to be chosen by US policymakers to pursue security because of a resumed security imperative from anarchy. US policy toward Asia after the Cold War is a case study to test the validity of the power-perception hegemonic model. I conclude that US policymakers should prepare for life after Pax-Americana, and early implementation of offshore balancing and multilateralism may facilitate the soft-landing of declining US hegemony.
\end{abstract}

Kai He is an Assistant Professor in the Department of Political Science at Utah State University. $\mathrm{He}$ is a postdoctoral fellow in the Princeton-Harvard China and the World Program at Princeton University (2009-2010) and a Bradley fellow of the Lynda and Harry Bradley Foundation (2009-2010). His research interests include foreign policy analysis, international security, international political economy, US-China Relations, Asian security, Chinese politics, and social science research methods. He is the author of Institutional Balancing in the Asia Pacific: Economic Interdependence and China's Rise (Routledge, 2009). He has also published articles in European Journal of International Relations, Security Studies, The Pacific Review, Journal of Contemporary China, Asian Security, Asian Perspective, and International Relations of the Asia Pacific.

\section{Introduction}

No one can deny that the US has been the most powerful state in the world by any measure since the end of the Cold War. While most other states are worried about how to live with the hegemon, US policymakers and scholars debate how to prolong

\footnotetext{
* The author owes special thanks to Huiyun Feng, Sheldon Simon, Stephen Walker, and anonymous reviewers of the Review of International Studies for their constructive comments and suggestions. An earlier version of this article was presented at the 2007 Annual Convention of the American Political Science Association in Chicago, USA.
} 
US primacy, and more importantly, how to exercise the preponderant power of the US more effectively in the world. After the Cold War, US strategists have suggested four policy choices for the hegemon: hegemonic dominion, selective engagement, offshore balancing, and multilateralism. ${ }^{1}$

The hegemonic dominion strategy aims at maximising US military power and control in the globe in order to prevent the emergence of a 'peer competitor'. Selective engagement assumes that US security depends on its active balancing behaviour in the regions where US vital interests are involved. ${ }^{3}$ Offshore-balancing suggests that the US should preserve its power or hegemony in its own hemisphere and conduct extra-regional balancing only when other potential regional hegemons are on the horizon. ${ }^{4}$ Some scholars argue as well that the US should become a latent hegemon who exercises its power and influence within multilateral institutions because multilateral institutions can not only legitimise but also facilitate US leadership in the world. ${ }^{5}$

These four well-argued and theory-driven strategies indicate different policy choices for the US. However, one interesting puzzle is that the real US foreign policy after the Cold War looked quite different from any single strategy advocated by scholars. Although US policy under George W. Bush is close to what the hegemonic dominion policy advocates, it is highly unlikely that any presidential candidate will continue this policy after 2008. The selective engagement strategy seems to catch major features of US foreign policy after the Cold War, such as US forward deployment and the tightened bilateral alliances. However, it appears weak in accounting for Clinton's embrace of multilateralism in the mid-1990s and Bush's pre-emption strategy in the early 21st century. A similar limitation applies to the other two policy options as well. In other words, we cannot use a single strategic framework to explain US foreign policy after the Cold War.

In this article a power-perception hegemonic model integrates the four contending policy options to explain the evolution of US foreign policy under three different hegemonic conditions. The theoretical prerequisite of the model is that the US has achieved its hegemony since the end of the Cold War. By using US policymakers' perceptions of its hegemonic status in the international system as a benchmark, the model categorises three types of conditions for the hegemon: rising hegemony, stable hegemony and declining hegemony. It specifies that the strategy for US foreign policy depends on how US policymakers perceive the hegemonic status of the US in the international system as follows: (1) If US policymakers perceive continuous ascendancy of US power - rising hegemony - selective

${ }^{1}$ For excellent reviews on different strategies for the US, see Barry Posen and Andrew Ross, 'Competing Visions of US Grand Strategy', International Security, $21: 3$ (1996/97), pp. 5-53; Robert Art, A Grand Strategy for America (Ithaca: Cornell University Press, 2003).

${ }^{2}$ See Charles Krauthammer, 'The Unipolar Moment', Foreign Affairs, 70:1 (1990/1), pp. 23-33; William Kristol and Robert Kagan, 'Toward a Neo-Reaganite Foreign Policy', Foreign Affairs, 75:4 (1996), pp. 18-32.

3 Art, A Grand Strategy for America, chs. 6 and 7.

${ }^{4}$ Christopher Layne, The Peace of Illusions: American Grand Strategy from 1940 to the Present (Ithaca: Cornell University Press, 2006); John Mearsheimer, The Tragedy of Great Power Politics (NY: Norton, 2001), ch. 10; and Stephen Walt, Taming American Power: The Global Response to US Primacy (N.Y.: W. W. Norton, 2005), ch. 5.

${ }^{5}$ G. John Ikenberry, After Victory: Institutions, Strategic Restraint, and the Rebuilding of Order after Major Wars (N.J: Princeton University Press, 2001) and Joseph Nye, The Paradox of American Power: Why the World's Only Superpower Cannot Go It Alone (New York: Oxford, 2001). 
engagement is the most likely policy choice because a rising hegemon is less constrained by the security imperative imposed by anarchy; (2) If US policymakers perceive that the US is in a power primacy position of stable hegemony, they are likely to choose a policy of hegemonic dominion; (3) If US policymakers believe that US power is in relative decline, under declining hegemony offshore balancing and multilateralism are more likely to be chosen to preserve security because policymakers tend to resume their anarchic view of the international system.

\section{Hegemony, perceptions, and policy choices}

After the Cold War the US became the only superpower, holding 'on to its accidental hegemony. ${ }^{6}$ The demise of the Soviet Union eliminated the only tangible threat of the US during the Cold War. Because of its predominant power the US virtually faces no military threats from any other countries under unipolarity. ${ }^{7}$ There are four strategies on the table for the US, the hegemon, to choose: selective engagement, hegemonic dominion, offshore balancing, and multilateralism. While the first three are rooted in various realist theories, the last one mainly stems from the liberal tradition.

\section{One hegemon and four strategies}

Selective engagement requires the US to retain its military alliances and keep large military forces deployed in Europe, Asia, and the Middle East/Persian Gulf where US vital interests are deeply involved. As Posen and Ross suggest, the theoretical root of selective engagement is deeply in classical realism, which emphasises the 'lust for power' in US policymaking. ${ }^{8}$ In the latest elaboration of selective engagement, Art suggests that homeland security against the grand terrorist attack is the first vital interest of the US. ${ }^{9}$ Since international terrorists are not constrained by any territorial boundary, selective engagement virtually applies to anywhere in the globe.

The major problem of selective engagement is how to make the selection of so-called vital interests. Geographically, selective engagement sets Europe, Asia, and the Middle East/Persian Gulf as the first priority because Europe and Asia are

\footnotetext{
${ }^{6}$ Barry Posen, 'Command of the Commons: The Military Foundation of US Hegemony', International Security, 28:1 (Summer 2003), p. 19. Hegemony is a contested definition. Here I use hard power, that is, military and economic capabilities, to define US hegemony after the Cold War. For a discussion of the definition of hegemony, see John Mearsheimer, The Tragedy of Great Power Politics, p. 40; Robert Gilpin, War and Change in World Politics (Cambridge: Cambridge University Press, 1981), pp. 29-30; and Layne, 'The Unipolar Illusion Revisited', International Security, 31:2 (2006), pp. 11-2.

7 It is argued that terrorism is a new form of security concern for the US after 9/11. While acknowledging the impacts of terrorist attacks on US security, I argue that terrorism cannot change the nature of international politics which is based on the interactions between sovereign states. For a similar argument, see Robert Jervis, 'Theories of War in an Era of Leading-Power Peace', American Political Science Review, 96:1 (2002), pp. 1-14.

${ }^{8}$ Posen and Ross, 'Competing Visions for US Grand Strategy', 17. Note 13.

${ }^{9}$ Art, A Grand Strategy for America.
} 
the centre of industrial powers and the Middle East controls the resource of oil supplies for the US. During Bush's war on terror, Southeast Asia was treated as the 'second front of US war on terror.' ${ }^{10}$ In the same line of argument, if terrorists appear in Africa, Africa should be the place deserving US military engagement as well. Selective engagement then will become 'global engagement.'

Along with the increase of US power, selective engagement will inevitably extend to hegemonic dominion, which also stems from the classical realist school of thought. ${ }^{11}$ The only difference between selective engagement and hegemonic dominion lies in the degree of US military engagement. When the US claims that it will not hesitate to use force to prevent great power wars in a certain region, it is selective engagement. However, when the US is willing to use military power to unilaterally solve any problem in the world, it is hegemonic dominion.

The major criticism of hegemonic dominion centres on the limit of US material power and the possible counterbalancing from other states. First, although the US is an unprecedented hegemon with unparalleled material power, the US cannot force other states to do whatever it desires. In other words, material power has its limitations. ${ }^{12}$ Second, a US aggressive policy will cause global resentment and resistance from other great powers. Although military counterbalancing may be delayed, other states can use various soft-balancing strategies to tame American power. $^{13}$

Challenging classical realism-rooted selective engagement and hegemonic dominion, structural realists suggest offshore balancing as an alternative realist strategy for the US. Offshore balancing advocates withdrawing US military forces from overseas bases and preserving its power and influence in the western hemisphere. Offshore balancing does not equal isolationism, because it supports necessary intervention or balancing behaviour in the region where a hostile power intends to pursue hegemony. Differing from selective engagement and hegemonic dominion, offshore balancing suggests a self-restricted policy for preserving US security in the international system.

Interestingly, many leading structural realists advocate this offshore-balancing strategy from different perspectives. Following balance of power theory, Layne suggests that the US should foresee the inevitable multipolar world and preserve its power position as an offshore balancer by 'standing on the sidelines while other great powers enervate themselves in security competitions with one another.' ${ }^{14}$ Based on balance of threat theory Walt argues for the offshore balancing strategy

${ }^{10}$ John Gershman, 'Is Southeast Asia the Second Front?, Foreign Affairs, 81 (2002), pp. 60-74.

11 The hegemonic dominion strategy is named as 'primacy' by Barry Posen, 'dominion' by Robert Art, or 'global hegemony' by Stephen Walt. For the hegemonic dominion strategy, see Charles Krauthammer, 'The Unipolar Moment', Foreign Affairs, 70:1 (1990/1), pp. 23-33; William Kristol and Robert Kagan, 'Toward a Neo-Reaganite Foreign Policy', Foreign Affairs, 75:4 (1996), pp. 18-32. As Walt suggests, the implicit implementation of the hegemonic dominion strategy is Bush's National Security Strategy (Washington: The White House, 2002). See Stephen Walt, Taming American Power: The Global Response to US Primacy (N.Y.: W. W. Norton, 2005), pp. 298.

${ }^{12}$ For the limitation of hard power, see Joseph Nye, Soft Power: The Means to Success in World Politics (New York: Public Affairs, 2004).

${ }^{13}$ For a discussion on soft-balancing, see Robert Pape, 'Soft Balancing against the United States', International Security, 30:1 (2005), pp. 7-45; T. V. Paul, 'Soft Balancing in the Age of US Primacy', International Security, 30:1 (2005), pp. 46-71.

14 Layne, Peace of Illusions, p. 161. 
because it helps the US reduce global resentments against the US threat. ${ }^{15}$ Mearsheimer from an offensive realist perspective argues that the US cannot become a global hegemon due to the stopping power of water in the first place. Therefore, the US should maintain its regional hegemony in the western hemisphere and withdraw its overseas troops. What the US should do is to pass the buck (the balancing responsibility) to other great powers if possible. ${ }^{16}$ Differing from selective engagement and hegemonic dominion, different variants of offshore balancing strategy suggests a similar self-restricted policy for the hegemon in the international system.

The major criticism of offshore balancing is that it is not compatible with the age of globalisation. Many scholars point out that US national interests are indivisible with the interdependent outside world and any regional conflicts will hurt US economic interests and security at home. Theoretically, offshore balancing is a smart and ideal policy to preserve US power as the last resort during great power conflicts. However, it is not a practical policy because US economic and political interests need US military protection in the first place. Therefore, Art points out that in the short run offshore balancing is less risky and costly. But in the medium to longer term, [offshore balancing] would pose greater risks to America's interests and could, consequently, impose greater costs while bringing fewer benefits.' 17

Last but least, many scholars, from different theoretical perspectives; suggest that the US should rely on multilateral institutions to exercise its unparalleled power. Liberals believe that the US is a benign hegemon in nature and institutions are compatible with US liberal ideology and practice. ${ }^{18}$ Hegemonic stability theorists suggest that the hegemon can use institutions to provide public goods, legitimise leadership, reduce transaction costs, and encourage cooperation among states. ${ }^{19}$ Some realists, however, think institutions can help the US exert its influence more effectively and less aggressively in the world. ${ }^{20}$ In addition, social constructivists believe that the US should be better off strategically if it constructs

15 See Walt, Taming American Power: The Global Response to US Primacy, pp. 223-47.

16 See Mearsheimer, Tragedy of Great Power Politics, ch. 10.

${ }^{17}$ Indeed, it is hard to calculate real costs and benefits of the offshore balancing strategy for the United States. Art argues that the United States should have been better off if it had committed its military power to Europe after World War I, then World War II might have been avoided. US offshore balancing after World War I caused the US over one million casualties. However, many historians also pointed out that without World War II, the US could not rise to be a superpower. US current unparalleled power is partly built on the US victory in World War II. Art, A Grand Strategy for America, p. 216; Art, A Grand Strategy for America, p. 216.

${ }^{18}$ See G. John Ikenberry, After Victory: Institutions, Strategic Restraint, and the Rebuilding of Order after Major Wars. It is worth noting that Ikenberry also suggests the 'lock-in' function of multilateral institutions in that the hegemon can use multilateral institutions to constrain others' behaviour in the anarchic system.

${ }^{19}$ Hegemonic stability theory traditionally focuses on the economic arena rather than the security realm. However, as Mastanduno suggests, hegemonic stability theory can be also applied to the analysis of the security order under unipolarity. See Michael Mastanduno, 'Incomplete Hegemony and Security Order in the Asia-Pacific', in G. John Ikenberry (ed.), America Unrivaled: The Future of the Balance of Power (Ithaca: Cornell University Press, 2002), pp. 181-212.

${ }^{20}$ For realist multilateralism, see Henry Kissinger, Does America Need a Foreign Policy (New York: Simon \& Schuster, 2001); and Zbigniew Brzezinski, The Choice: Global Dominion or Global Leadership (New York: Basic Books, 2004). 
some security communities based on common ideologies and norms. ${ }^{21}$ One similarity of these different theoretical arguments is that all advocate the US leadership in multilateral institutions. It is worth noting that the theoretical boundary in the study of multilateralism is sometimes arbitrary and blurred since scholars are pragmatically employing different theories in their research. ${ }^{22}$

The major problem of multilateralism is that it is good in theory but poor in practice. Theoretically, the US should rely on multilateral institutions to exercise its power and influence. In reality, America seems less patient with multilateral institutions, which we can see from its strained relations with the UN and other global multilateral institutions after the Cold War. Indeed, it is sensible for the US to ignore or at least downplay the role of multilateral institutions for two reasons. First, if the unparalleled material power can help the hegemon get most, if not all, what it wants, there is no incentive for the hegemon to consider multilateral institutions. Second, institutions will inevitably constrain a hegemon's freedom of action although the hegemon may get the 'lion's share' within those institutions. It is questionable whether the hegemon is willing to pay any additional price for the 'lion's share' if power can ensure the hegemon of getting the most it wants. ${ }^{23}$ It is not to say that the hegemon will abandon multilateral institutions. Rather, the hegemon will pragmatically use multilateral institutions to fulfil its interests if necessary. ${ }^{24}$ Multilateralism will not be a major strategy for the hegemon when its preponderant power can easily solve any problem it faces.

In sum, no one theory or strategy can fully explain US policy under unipolarity after the Cold War. There are two possible reasons for the discrepancy between theory and real policy in the study of US foreign policy. First, the complex nature of the decision-making process of the US leads US foreign policy to be an 'uneasy amalgam' of different strategies. For example, Posen and Ross suggest that Clinton's foreign policy consists of the major elements of three different strategies: cooperative security, primacy, and selective engagement in the 1990s. ${ }^{25}$ Second, we need an integrated, dynamic theory to explain the evolution of US foreign policy over time. Although these four policy options are all sensible to advance US security or primacy, they might only apply under certain strategic conditions. In other words, US policymakers pick and choose different strategies on the table to cope with the dynamic situations they encounter in the international system.

\section{A power-perception hegemonic model - power vs. security}

While acknowledging the first possibility, this article explores the second possibility by introducing a dynamic theoretical framework - a power-perception hegemonic

${ }^{21}$ For a collective security argument, see Charles Kupchan, The End of the American Era: US Foreign Policy and the Geopolitics of the Twenty-First Century (New York: Random House, 2002).

${ }^{22}$ For a theoretical combination including the security community argument, see Robert Jervis, American Foreign Policy in a New Era (New York: Routledge, 2005).

${ }^{23}$ See Randall Schweller, 'The Problem of International Order Revisited', International Security, 26:1 (2001), pp. 161-86.

${ }^{24}$ Michael Mastanduno, 'US Foreign Policy and the Pragmatic Use of International Institutions', Australian Journal of International Affairs, 59:3 (2005), pp. 317-33.

25 See Posen and Ross, 'Competing Visions of US Grand Strategy.' 
model - to explain US policy choices under different strategic conditions. I suggest that: (1) US policy is shaped by policymakers' different perceptions about US hegemony after the Cold War; (2) depending on different stages of US hegemony, US policymakers face different constraints from the international system and therefore choose either power-maximisation policy or security-maximisation policy; (3) while selective engagement and hegemonic dominion are two power-pursuing policies, offshore balancing and multilateralism can help the US maintain security under the anarchic system.

The power-perception model of hegemonic status is a neoclassical realist theory, which emphasises the necessity of finding a transmission belt between systemic effects and state behaviour. ${ }^{26}$ The systemic effect of the distribution of power is the major independent variable in explaining state behaviour. As Fareed Zakaria points out, 'the most powerful generalizable characteristic of a state in international relations is its relative position in the international system. ${ }^{27}$ However, the effects of power configuration in the system cannot directly dictate state behaviour, but have to be transmitted through leaders' perceptions in order to influence states' foreign policy choices. William Wohlforth applies a similar model to explain Soviet foreign policy towards the US and argues that after perceiving a decline in power, the Soviet Union had no incentive to militarily challenge the US. Therefore, the Cold War ended peacefully. ${ }^{28}$ While Wohlforth discusses how the power-perception changes affect the challenger's policy toward the status quo power in a power-transition cycle, I examine how the hegemon's perceptions regarding its power dynamics shape its foreign policy choices toward other states in a power cycle of hegemony.

The US has been the hegemon by default in the international system since the demise of the Soviet Union. However, why did not the US follow an explicit hegemonic dominion policy prior to George W. Bush? The answer can be found in the important role of policymakers' perceptions. As Wohlforth points out, what really matters in policy making is not power per se, but decision makers' assessment of power. ${ }^{29}$ By any standard the US is the most powerful state in the system. However, its relative power status vs. others changes over time. For US policy makers there are three perceptual stages regarding the manifestation of US hegemony.

The first perceptual stage of US hegemony is a rising hegemony during which time the relative power advantage of the US continues to grow even after the US reaches its power primacy under unipolarity. In other words, the power gap between the US and other states in the system is not narrowed, but widened, although other states are trying to catch up with the US in the system all the time.

The second stage is stable hegemony when the US enjoys enough power primacy over other states to last at least 20 years. Under stable hegemony, US power may or may not increase at the pace it achieved before. However, the

${ }^{26}$ Gideon Rose, 'Neoclassical Realism and theories of Foreign Policy', World Politics, 51:1 (1998), pp. 144-72.

27 Fareed Zakaria, 'Realism and Domestic Politics', International Security, 17:1 (1992), p. 197.

${ }^{28}$ William Wohlforth, 'Realism and the End of the Cold War', International Security, 19:3 (1994/95), pp. 91-129.

29 Wohlforth, 'Realism and the End of the Cold War', p. 97. Also see Wohlforth, 'The Perception of Power: Russia in the Pre-1914 Balance', World Politics, 39:3 (1987), pp. 353-81; and The Elusive Balance: Power and Perceptions during the Cold War (Ithaca: Cornell University Press, 1993). 
marginal power advantage of the US in the system can retain its power gap with others for a stable period of time. Thus, US policymakers can be sure that other states will not threaten US security for at least 20 years even if the increase of US power slows down for a while.

The third stage is declining hegemony. After the US experiences stagnation in power acquisition for a period of time with other great powers catching up rapidly, the power gap between the US and others significantly narrows. Although the US may remain the most powerful state in the system in an absolute sense, its relative power vs. its competitors decreases dramatically.

At the rising and stable hegemony stages, the US faces less security constraints from the international system. Although the system is still anarchic in nature, in the eyes of US policymakers the anarchic system has been transformed into a hierarchic order in practice with the US at the top. It does not necessarily mean that the US is omnipotent in getting whatever it wants. However, its preponderant power can at least keep the US immune from what other states worry all the time under anarchy - security.

As Kenneth Waltz points out, 'In anarchy, security is the highest end. Only if survival is assured can states safely seek such other goals as tranquility, profit, and power. ${ }^{30}$ When its survival/security is largely assured given its unchallenged power, the US inevitably seeks more power because of human nature's lust for power. Although the 'lust for power' in realist philosophy ${ }^{31}$ may have some influence on US foreign policy during bpolarity and multipolarity as well, the security imperative imposed by anarchy overshadows US ambitions about power. Under unipolarity, the US lust for power is unleashed and US foreign policy is inevitably inclined to pursuing more power than security.

At the declining hegemony stage, the US has to resume its concerns about security in the international system because the relative decline of US power makes security threats from other rising powers not only feasible but inevitable under anarchy. Either because of the diminishing returns of US power increases, or because of the differential economic growth rate between the US and others, American policymakers will eventually perceive a decline of hegemony when the power gap between the US and other great powers is significantly narrowed. ${ }^{32}$ When the relative power of the US is declining, US policymakers will have to worry about its security in the coming anarchy of a multipolar world. Although the US may be still the most powerful state in the system during the early declining period, the perceived loss of relative power advantage will force US policymakers to change their earlier, hierarchic view of the international system. The US is no longer immune from military threats from other great powers because of the decline of US relative power in the system. Security rather than power will become the first strategic priority for the declining US in the anarchic international system.

${ }^{30}$ Waltz, Theory of International Politics (New York: McGraw-Hill, 1979), p. 126.

${ }^{31}$ Hans Morgenthau, Scientific Man vs. Power Politics (Chicago: University of Chicago, 1954), pp. 90-5, cited in Randal Schweller, 'The Progressiveness of Neoclassical Realism', in Colin Elman and Miriam Fendius Elman (eds), Progress in International Relations Theory (Cambridge: MIT Press, 2003), p. 323.

${ }^{32}$ For the argument regarding differential economic growth rates and the fall of a hegemon, see Robert Gilpin, War and Change in World Politics (Cambridge: Cambridge University Press, 1981). 


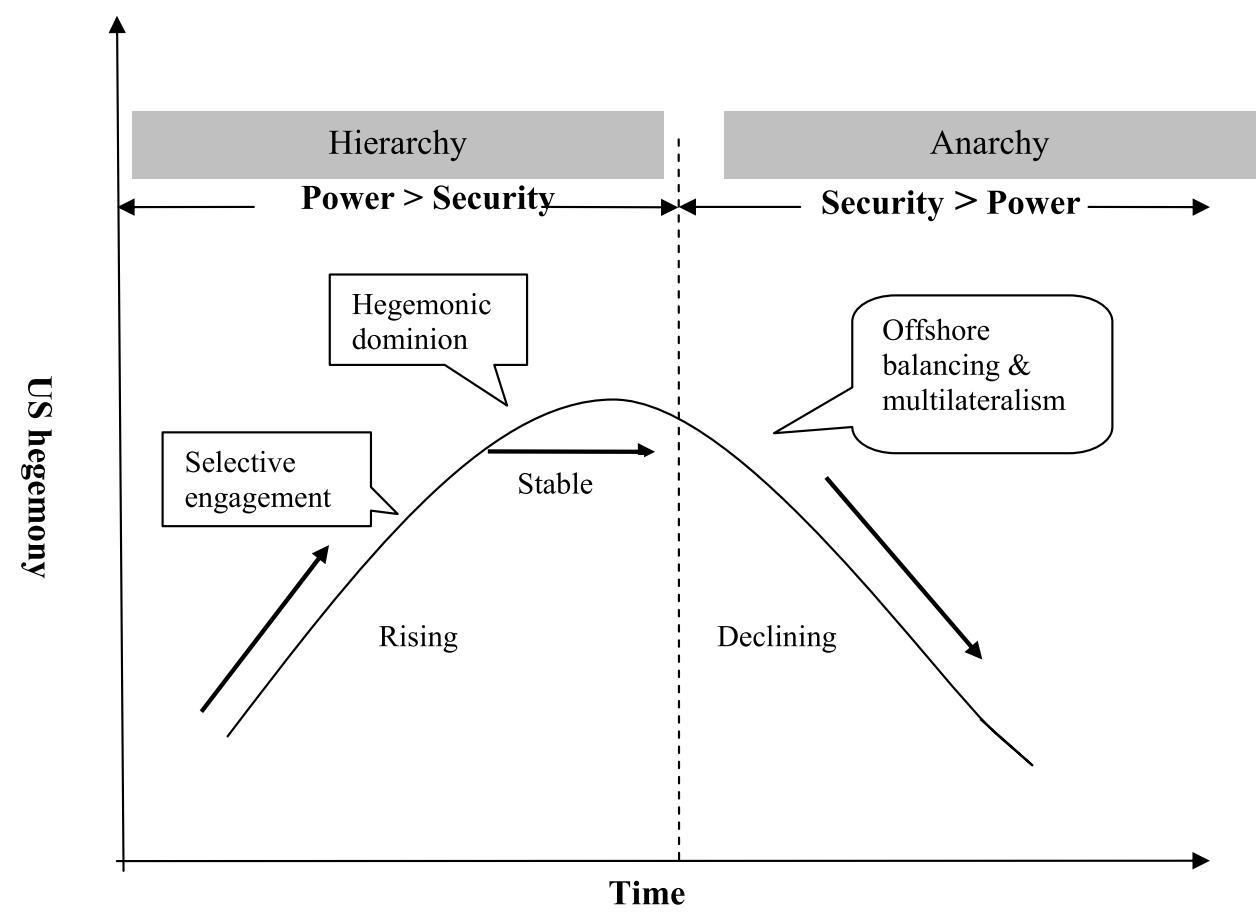

Figure 1. The power-perception hegemonic model - choice between power and security.

In sum, US hegemony has basically three perceptual stages: rising hegemony, stable hegemony, and declining hegemony. When US policymakers perceive the rising and stable hegemony, power-maximisation becomes the strategic goal of US foreign policy. Consequently, selective engagement and hegemonic dominion are the two most likely strategies for the US. However, when US policymakers perceive the declining hegemony, offshore balancing and multilateralism can help the US to maximise its security and economic interests in the anarchic system. The power-perception hegemonic model is illustrated in Figure 1.

Two caveats are worth noting. First, Figure 1 is an idealised model, simplified to illustrate the transformation of the three stages of hegemony as well as the possible strategies for the hegemon. In reality, the power transition of the hegemon is by no means as smooth as Figure 1 shows. The power curve of the hegemon may be disturbed by several fluctuations in the rise and fall of the hegemon in the system. The power reality also has to be transformed to policy outcomes through policymakers' perceptions. However, policymakers may have inconsistent or contending perceptions on the power reality of the hegemon's situation, which may result in temporary 'dips' or 'spikes' that deviate from the general trajectory of the idealised model.

Second, the power-perception hegemonic model does not discuss whether and when the hegemon will wage war to pursue power or security under different stages of hegemony. As Mearsheimer points out, "war is the most controversial strategy that great powers can employ to increase their share of world power.' 33 There is 
an intense debate about whether conquest or military victory pays or not. ${ }^{34}$ Therefore, this model does not list 'waging war' as a grand strategy, but it is a possible outcome of different strategies of the hegemon. Acknowledging the wisdom of different power transition and power cycle theories, this model also recognises that the change of relative power in the international system may cause military conflicts among states. However, rather than debating over who is more likely to initiate war during the power transition, the model focuses on examining the hegemon's policy choices at the different stages of hegemony. ${ }^{35}$

\section{US policy in Asia after the Cold War - a preliminary test}

To test the validity of the power-perception hegemonic model, I examine US foreign policy toward Asia after the Cold War, which was identified earlier as one of the geographic locations of US vital interests. ${ }^{36}$ The two hypotheses derived from the power-perception hegemonic model are:

H1. If US policymakers perceive the US as a rising or a stable hegemon, respectively, they are more likely to choose selective engagement or hegemonic dominion to pursue power.

H2. If US policymakers perceive a decline in the hegemony of the US, they are more likely to choose offshore balancing and multilateralism to pursue security.

Theoretically, the US has become a hegemon by default since the end of the Cold War. Whether the US hegemony has been in decline is still a debatable question so far. Therefore, it is still too early to directly test $\mathrm{H} 2$ in which the US experiences a decline in hegemony. However, the strategic uncertainty soon after the Cold War precluded US policymakers from claiming its unparalleled hegemony in the first half of the 1990s. The US did not explicitly conduct the dominion strategy until the George W. Bush administration in 2002. In this research, this uncertainty period in the early $1990 \mathrm{~s}$ is treated as a temporary 'dip' on the trajectory of US rising hegemony.

${ }^{34}$ For the conquest-does-not-pay argument, see Kennedy, The Rise and Fall of the Great Powers; Gilpin, War and Change in World Politics; and Stephen Van Evera, Causes of War: Power and the Roots of Conflict (Ithaca: Cornell University Press, 1999). For the conquest-does-pay argument, see Peter Liberman, Does Conquest Pay? The Exploitation of Occupied Industrial Societies (Princeton: Princeton University Press, 1996).

35 There are contending arguments on which party is more likely to initiate wars during the power transition period. A. F. K. Organski suggests that the rising, dissatisfied powers are more likely use force to turn down the status quo of the system. Dale Copeland's dynamic differentials theory challenges Organski's argument by suggesting some strategic conditions under which the dominant but declining military great powers are more likely to initiate a major war. Gilpin is inclined toward Organski's theory, but he also recognises that a declining power may initiate wars for preventive reasons. Charles Doran and Wes Parsons suggest that the dramatic change of relative powers, including increase and decline, at certain critical points, are more likely to cause extensive wars among states. See A. F. K. Organski, World Politics (New York: Alfred A. Knopf, 1958); Dale Copeland, The Origins of Major War; Robert Gilpin, War and Change in World Politics; and Charles Doran and Wes Parsons, 'War and the Cycle of Relative Power', The American Political Science Review, 74:4 (1980), pp. 947-65.

${ }^{36}$ Asia here is narrowly defined to include East Asia and Southeast Asia countries only. US policy toward South Asia and Central Asia are not discussed. 


\begin{tabular}{|c|c|c|c|}
\hline $\begin{array}{l}\text { Variables and } \\
\text { indicators in } \\
\text { power-perception } \\
\text { model of hegemony }\end{array}$ & $\begin{array}{l}\text { Declining hegemony } \\
\text { (or a temporary 'dip' } \\
\text { in rising US } \\
\text { hegemony) }\end{array}$ & Rising hegemony & Stable hegemony \\
\hline Time period & $1990-1994$ & $1995-2000$ & $2001-2008$ \\
\hline Power realities & $\begin{array}{l}\text { US economy in } \\
\text { recession and dual } \\
\text { deficits }\end{array}$ & $\begin{array}{l}\text { US 'New Economy'; } \\
\text { Asian Economic } \\
\text { crisis reconfirms US } \\
\text { hegemony; US won } \\
\text { Kosovo and Bosnia } \\
\text { Wars }\end{array}$ & $\begin{array}{l}\text { US fought back the } \\
\text { terrorist attacks by } \\
\text { successfully invading } \\
\text { Afghanistan and } \\
\text { Iraq; US military } \\
\text { spending reached } 50 \\
\text { per cent of total } \\
\text { military expenditure } \\
\text { in the world. }\end{array}$ \\
\hline Perception shifts & $\begin{array}{l}\text { 'Japan is } \\
\text { unquestionably an } \\
\text { economic superpower } \\
\text { [...]' and 'most } \\
\text { nations [in the } \\
\text { region], for reasons } \\
\text { of national pride, } \\
\text { increasingly desire to } \\
\text { be less reliant on the } \\
\text { US.' (the 1990 East } \\
\text { Asia Strategic } \\
\text { Initiative) }\end{array}$ & $\begin{array}{l}\text { The US would } \\
\text { 'maintain the } \\
\text { best-trained and } \\
\text { best-led military force } \\
\text { in the world' in order } \\
\text { to ensure that 'US } \\
\text { forces [...] have } \\
\text { unchallenged } \\
\text { superiority in the } 21 \text { st } \\
\text { century' (the } 1998 \\
\text { National Security } \\
\text { Strategy) }\end{array}$ & $\begin{array}{l}\text { The US would not } \\
\text { allow any adversaries } \\
\text { to be even 'in hopes } \\
\text { of surpassing, or } \\
\text { equaling, the power } \\
\text { of the US.' (the } 2002 \\
\text { National Security } \\
\text { Strategy) }\end{array}$ \\
\hline Policy changes & $\begin{array}{l}\text { Offshore balancing } \\
\text { (withdraw troops } \\
\text { from Asia) and } \\
\text { Multilateralism } \\
\text { (active role in APEC } \\
\text { and ARF) }\end{array}$ & $\begin{array}{l}\text { Selective engagement } \\
\text { (Stop troop reduction } \\
\text { plan; strengthen } \\
\text { bilateral alliances and } \\
\text { military ties in Asia) }\end{array}$ & $\begin{array}{l}\text { Hegemonic dominion } \\
\text { (pre-emption } \\
\text { doctrine) }\end{array}$ \\
\hline
\end{tabular}

Table 1. Power, perception, and policy dynamics in US policy in Asia after the Cold War

Table 1 shows the roadmap for the case study of US foreign policy toward Asia. By tracing US policy toward Asia under the three post-Cold War Presidents, I examine how the changing perceptions of US policymakers regarding US hegemony led to different US strategies in Asia. Although it is still not clear when the US will enter the declining hegemony period, this research can shed some light on the future policy orientation of the US based on its early experience of hegemony. It should be noted that the time periods of US hegemony are categorised approximately for analysis. Empirically, the perceptions of individual policymakers may not exactly agree. The dates for each time period are intended to reflect the prevailing public view of hegemony among US leaders expressed in authoritative government documents and official statements.

\section{US Asian policy (1989-1995) - offshore balancing and multilateralism}

The sudden collapse of the Soviet Union left the US as the sole superpower in the world in 1991. By virtually any measure, America was unrivalled. However, how 
long this 'unipolar moment' could last was highly controversial in the US. During the first part of the 1990s, US policymakers held a contested, uncertain perception regarding US hegemony, and the declinist view widely spread in the US.

In the late 1980s, public concerns about America's decline first arose when the US economy faced 'dual deficits' - budget and trade deficits - during the Reagan administration. The Reagan presidency left two legacies to President George H. W. Bush in 1989: political triumph and economic burden. The US won its first overseas military action since the Vietnam War in Iraq and witnessed the collapse of Soviet Union in 1991. However, Reagan's 'supply-side economics' policy, that is, combining individual tax cuts and heavy military spending, also caused a mounting budget deficit in 1990. The US government deficit was \$74 billion in 1980 and reached $\$ 220.5$ billion in 1990. In addition, the US suffered a \$101.7 billion trade deficit even though its exports had expanded towards Asia and Eastern European countries. ${ }^{37}$ The US GDP growth rate fell from 3.53 per cent in 1989 to 1.86 per cent in 1990 and experienced a negative growth of -0.19 per cent in $1991 .{ }^{38}$ Although the US economy slowly recovered in 1992, the huge economic burden of the 'dual deficits' from budgets and trade was not relieved until the second part of the 1990s.

Contrary to the serious domestic fiscal and social problems the US faced in the early 1990s, Asian economies had boomed from the 1980s. In 1965, Asia-Pacific economies (including Australia and New Zealand) together only accounted for one-quarter of US GNP, but they matched the US GNP in the early 1990s. ${ }^{39}$ In particular, Japan was widely perceived to be replacing the US as the next powerhouse in Asia. In foreign investment, Japan exceeded the total US foreign investment in the region and took a leading share in almost all countries. In international aid, Japan also replaced the US as the predominant provider in Asia in the early 1990s. ${ }^{40}$ The share of US international trade in the Asia-Pacific was also gradually decreasing. For example, the proportion of South Korean trade with the US in its total trade fell from 36 per cent in 1970 to 27 per cent in 1990. The proportion of Japanese exports sold in the US was 40 per cent in the 1980s while it decreased to 28 per cent in $1990 .{ }^{41}$ Intra-regional trade in Asia had become the driving force of rapid economic growth in Asia. The relative decline of the US was inevitable as a by product of Asia's economic rise in the early 1990s.

There are at least two reasons to believe that the declinist view was a prevailing perception in Washington in the early 1990s although US political elites only reluctantly recognised the decline of US power in public. First, US government officials frequently emphasised the rise of Asia in their public statements and speeches. For example, the 1990 East Asia Strategic Initiative (EASI) observed that 'Japan is unquestionably an economic superpower - the world's largest creditor and [...] one of the two largest providers of economic assistance', and 'most

${ }^{37}$ Conte Christopher and Albert R. Karr, An Outline of the US Economy (Washington D.C.: US Department of State, 2001), available online at: $\{$ http://usinfo.state.gov/products/pubs/oecon/\}.

38 The Statistical data are from World Development Indicator by the World Bank, WDI online at: \{www.wdi.org\}.

39 Donald Crone, 'Does Hegemony Matter? The Reorganization of the Pacific Political Economy', World Politics, 45:4 (1993), p. 509.

40 Detailed statistics are in Donald Crone, 'Does Hegemony Matter?'. v. 508.

${ }^{41}$ Statistical data are from UN Handbook of Statistics (web version): $\{$ http://www.unctad.org/ $\}$. Also see Karl Jackson, 'How to Rebuild America's Stature in Asia', Orbis, 39:1 (1995), pp. 11-8. 
nations [in the region], for reasons of national pride, increasingly desire to be less reliant on the US. ${ }^{42}$ In 1991, Richard Solomon, Assistant Secretary for East Asian and Pacific Affairs in the Bush Administration, stated, 'The Asian-Pacific region has not been unaffected by the trends now transforming Europe [...] As the overlay of US-Soviet competition in the Pacific diminishes, East Asia's traditional multipolarity is becoming increasingly pronounced. ${ }^{43}$ US officials seemed to recognise the trade-off effect between Asia's rise and the relative decline of US influence in Asia.

Second, the US government assertively campaigned for sustaining its preeminent status in Asia which, in turn, reflected its self-perceived decline in power. US traditional strategic interests were articulated as 'preventing any hostile power from dominating the European and Asia-Pacific regions.' During the Cold War America contained the Soviet threat and influence in the world through NATO in Europe and a series of bilateral alliances in Asia. Given its unparalleled military might, the US seldom worried about its pre-eminent status in the Western Camp. However, after the Cold War, the US began to worry about its leadership role in the region. In 1992, according to the leaked draft of Defense Planning Guidance from the White House, the New York Times reported that the US government was planning to adopt a 'strategy of preponderance' to block any challenges to US global pre-eminence. ${ }^{44}$ In other words, the US government had been well aware of the possible decline of US power, given the global challenges after the Cold War. As Paul Kennedy suggests, 'when a Great Power is strong and unchallenged, it will be much less likely to debate its capacity to meet its obligations than when it is relatively weaker. ${ }^{45}$ The mere fact that the US worried about the challengers reveals its self-perceived, relative decline in power.

Recalling the power-perception hegemonic model, the US in the early 1990s can be categorised either as a declining hegemon or as experiencing a 'dip' period, that is, a temporary decline, in an upward power curve, because of the widespread perception of US decline. ${ }^{46}$ US foreign policy, therefore, should follow the offshore balancing and multilateralism strategies in Asia. US foreign policy toward Asia in the George H. W. Bush and the first Clinton administrations reflected the strategic orientations of offshore balancing and multilateralism.

First, the military withdrawal and defence budget cut in Asia in the George $\mathrm{H}$. W. Bush administration is a good manifestation of the offshore balancing strategy.

42 US Department of Defense, A Strategic Framework for the Asian Pacific Rim: Looking Forward the 21st Century (Washington, D.C.: Department of Defense, 1990), pp. 1-2.

${ }^{43}$ Richard Solomon, 'Security Challenges and Alliances in a New Era', US Department of State Dispatch, 2:33 (1991).

44 Douglas Stuart and William Tow, A US Strategy for the Asia-Pacific: Building a Multipolar Balance-of-Power System in Asia, Adelphi Paper, no. 299 (London: The International Institute for Strategic Studies, 1995), p. 7.

${ }^{45}$ Kennedy, Rise and Fall of Great Power, p. 530. It is interesting to note that many scholars use the leaked information from the New York Times to prove the hidden US ambition for hegemony in the early 1990s. See Layne, The Peace of Illusions, p. 25; and Art, A Grand Strategy for America, p. 88. The later published Defense Planning Guidance was toned down because of the strong public criticism. Rather than seeking a 'strategy of preponderance', it emphasises working with regional allies to preserve regional order. It is worth noting that the mere fact that the Bush government had to respond to public criticism reflects the lack of confidence in US hegemony in the early 1990s.

46 The power-perception model also applies to a 'dip' period as long as US policymakers perceive a decline of hegemony. The US may change its offshore balancing and multilateralism strategies later when the perception of hegemony alters in an upward direction. 
Just as the power-perception hegemonic model suggests, the domestic economic difficulties first hit US defence spending and overseas commitments. Although it is argued that US defence cuts in the early 1990s might be a response to the demise of Soviet threats, US economic recession was at least a similar important reason for the Congress to press the President. From 1990 to 1995, US defence spending was reduced by over 5 per cent per year in real terms, which represented a fall from 5.5 per cent of GDP to 3.9 per cent. $^{47}$

More importantly, as offshore balancing suggests, the US started to withdraw some troops from Asia to meet defence budget cuts in 1990. In Asia, the Bush administration planned to reduce US forces by $10-12$ per cent, about 14,000 to 15,000 personnel out of 135,000 forward deployed in the region in $1990 .{ }^{48}$ It was reported that the US planned to reduce over 100,000 US forces in Asia from 1990 to $2000{ }^{49}$ In 1992, the US withdrew its troops from Clark Air Base and Subic Naval Base in the Philippines. Although the US later signed or strengthened its military agreements with some ASEAN states, such as the logistical support arrangement with Singapore in 1992, the military bases closed in Southeast Asia were not replaced.

The strategic rationale behind the US military withdrawals from Asia under the Bush and the first Clinton administrations follows what the offshore balancing strategy suggests. Offshore balancing argues that the US should preserve its military primacy in the western hemisphere by reducing its overseas commitments. As an offshore balancer, the US should stand on the sideline to watch power struggles among regional powers in Asia. The US will not militarily involve or play the 'balancer' role in Asia until one state, such as China or Japan, tries to dominate the region. In addition, offshore balancing emphasises the importance of military mobility and cutting-edge technology in future warfare because the US needs to rapidly project its military power from its own hemisphere to Asia if necessary.

Compatible with offshore balancing, the US Department of Defense argued in the early 1990 s that 'by continuing to deploy around $6 \%$ of total forces [...] the US could still be a credible "regional balancer"" in the Asia-Pacific. ${ }^{50}$ Moreover, US military claimed that due to the advanced military and information technologies, the US did not need permanent military bases to project its power in Asia. These 'winning on the cheap' and 'place-not-base' arguments were widely criticised as unrealistic either because of its overestimation of capability in the region or because of its underestimation of military budget needs to implement such a strategy. ${ }^{51}$ However, if the strategic goal of the US was not to prevent great

${ }^{47}$ EIU (Economist Intelligent Union) Country Profile: the United States 1996-1997 (London: Economist Intelligent Union, 1996), p. 13.

${ }^{48}$ In November 1991, the US government froze its additional troop reduction plan of withdrawing 6,000 personnel from South Korea because of North Korea's possible nuclear program. See US Department of Defense, A Strategic Framework for the Asian Pacific Rim (Washington D.C., Department of Defense, 1992), p. 20.

${ }^{49}$ Regarding US post-Cold War military strategy in the Asia-Pacific, see Stuart and Tow, $A$ US Strategy for the Asia-Pacific, pp. 6-11.

${ }^{50}$ Stuart and Tow, A US Strategy for the Asia-Pacific, p. 10.

51 Alan Tonelson, 'Superpower Without a Sword', Foreign Affairs, $72: 3$ (1993); and Dov Zackheim and Jeffrey Ranney, 'Matching Defense Strategies and Resources: Challenges for the Clinton Administration', International Security: 18:1 (1993). 
power wars in Asia in the first place, but to become a balancer by last resort, this minimal deployment strategy of the US in Asia was well justified in the early 1990s.

After coming to power in 1993, President Clinton basically continued the Bush Administration's security retreat in Asia. The Bottom-Up Review issued by the Secretary of Defense in 1993 suggested further cutting the defense budget by $\$ 100$ billion worldwide, and military reduction in Asia continued until 1995. ${ }^{52}$ In addition, Clinton learned a good lesson from Bush's defeat in the election, so that he set the domestic economy rather than security as the first priority of foreign policy. Multilateralism, therefore, became an important diplomatic tool for the US to open the Asian market and revive the US economy in the first Clinton administration.

Initiated by Australia and Japan, the Asian-Pacific Economic Cooperation (APEC) was established in Canberra in 1989 with the aim to promote regional economic cooperation as well as tackle economic pressures from the EU (EU) and the North America Free Trade Agreement (NAFTA). The major reason for the US to support APEC was the declining economic leverage of the US in the Asia-Pacific in the early 1990s. As Donald Crone observes, 'For the US, the prospect of extensive erosion of security and economic positions in the Pacific induced new enthusiasm for regional cooperation [in the 1990s]. ${ }^{53}$

President Clinton placed economic revival through APEC as the top priority of US foreign policy toward Asia. In 1993, the Clinton administration announced the 'three pillars' of its foreign policy: economic growth, military strength, and support for democracy. ${ }^{54}$ Although cutting military spending and withdrawing troops might temporarily relieve the budgetary pressure, the foundation of US power and influence lies in its domestic economy. One of the reasons for US economic difficulties in the early 1990s was mounting trade deficits with Asian countries. Therefore, the Clinton Administration applied an 'Asia first and trade first' policy through the building of APEC. As Winston Lord, Assistant Secretary of State for East Asian and Pacific Affairs stated in March 1993, 'Economics is increasingly supplanting military considerations on our foreign policy agenda. More than ever our national security depends on our economic strength. With domestic renewal now America's highest priority, trade and investment are critical. And no region is more central for American economic interests than the world's most dynamic one - Asia. ${ }^{55}$

In July 1993, Clinton started his first overseas visits to Japan and South Korea and officially launched his 'New Pacific Community' policy toward Asia. The economic essential of Clinton's 'New Pacific Community' policy was to build a 'more open regional and global economy' in the Asia-Pacific. APEC, therefore, became the perfect vehicle for the US to pursue its economic liberalisation and free trade policy in the region. In November 1993, the US elevated the APEC meeting from the ministerial level to the leaders' summit and invited the leaders of APEC to Seattle for an unprecedented summit in the Asia-Pacific.

\footnotetext{
52 See Les Aspin, Report on the Bottom-up Review (Washington D.C.: Department of Defense, 1993).

53 Donald Crone, 'Does Hegemony Matter?', p. 522.

${ }^{54}$ Cited by Lasater, The New Pacific Community, p. 29.

55 Winston Lord, 'A New Pacific Community: Ten Goals for American Policy', opening statement at confirmation hearing for Assistant Secretary of State, Bureau of East Asian and Pacific Affairs, Senate Foreign Relations Committee (31 March 1993).
} 
The 1994 APEC meeting, with US efforts, passed the 'Bogor Goals' - the first timetable for achieving free and open trade and investment in the Asia-Pacific. The industrialised economies committed to the goal of free and open trade and investment no later than the year 2010 and the developing economies no later than the year 2020. ${ }^{56}$ In the 1995 APEC meeting held in Osaka, Japan, APEC members adopted the Osaka Action Agenda (OAA) which provided a framework for implementing the 'Bogor Goals' through trade and investment liberalisation, business facilitation and sectoral activities, underpinned by policy dialogues, economic and technical cooperation.

There are mainly two reasons for the US to embrace APEC in the first Clinton administration. First, the US intended to resume its leadership through multilateralism. Although US power was seemingly in decline due to domestic economic constraints, the US was still confident of being the dominant power in Asia after the Cold War. Through multilateral institutions the US could legitimise its eroding leadership with its still-dominant-power in the region. It is true that the US had to compromise its freedom of action and interests in multilateral institutions. However, declining hegemony forced the US to accept this price for the return of leadership.

Second, APEC was a multilateral means for the US to push for free trade and economic liberalisation in the region for the sake of its domestic economic revival. Since the 1980s, the US had encountered serious trade deficits with its Asian allies, especially with Japan. After the Cold War trade deficits accompanying domestic economic recessions made it imperative for the US to solve this trade imbalance problem with Asia. President Clinton stated in the 1993 APEC meeting in Seattle, 'We [the US] do not intend to bear the cost of our military presence in Asia and the burdens of regional leadership only to be shut out of the benefits of growth that stability brings [...] we must use every means available in the Pacific, as elsewhere, to promote a more open world economy [...]'. ${ }^{57}$

The reasons for the US to push for a 'more open economy' in Asia are straightforward. First, the US economy is productive, technological, dynamic, and export-competitive. Free market and economic liberalisation benefit the US economy more than Asian economies. Second, APEC, a multilateral arrangement, has many institutional functions facilitating economic liberalisation. For example, multilateral negotiations can reduce transaction costs that the US has to pay for bilateral negotiations with individual countries. In addition, as Ellis Krauss suggests, APEC 'would enable the US to work with the other countries of the region to pressure Japan to promote change [to open its domestic market] in a less offensive and more effective way than the bilateral pressure had done.' 58 Last, economic liberalisation echoed US liberal beliefs that free trade and increased economic interdependence would diminish prospects for wars. ${ }^{59}$

\footnotetext{
56 Martin Lasater, The New Pacific Community: US Strategic Options in Asia (Boulder: Westview Press, 1996), pp. 61-2.

57 Bill Clinton, 'Remarks by the President to Seattle APEC Host Committee' (Seattle: The White House), 9 November 1993.

${ }^{58}$ Ellis S. Krauss, 'Japan, the US, and the Emergence of Multilateralism in Asia', p. 482.

59 Michael Mastanduno, 'US Foreign Policy and the Pragmatic Use of International Institutions', Australian Journal of International Affairs, 59:3 (2005), pp. 317-33.
} 
In sum, the relative decline of US hegemony in the early 1990s led George H. W. Bush and Bill Clinton to conduct offshore balancing and multilateralism to cope with the strategic uncertainty after the Cold War. The strategic goal of Bush's military withdrawal and Clinton's APEC policy is to protect US military security and economic interests in the region. However, when its domestic economy revived in the middle of the 1990s, US policymakers began to change their perceptions of US hegemony and consequently adopted new strategies in Asia.

\section{US Asian policy (1995-2008) - selective engagement and hegemonic dominion}

The second part of the 1990s witnessed a revival of American primacy in Asia. Economically, the US sustained continuous economic growth from March 1991 to 2000, the longest peacetime economic expansion in history. By the mid-1990s, the US economy was characterised by decreased budget deficits, low inflation, and low unemployment rate. The US government announced its first surplus of $\$ 70$ billion in fiscal year 1998 and obtained a record surplus of \$236 billion in fiscal year 2000. US GDP growth rate stabilised between 2-4 per cent from 1995-2001 and real GDP grew by almost 40 per cent between 1991 and 2001, equivalent to an annual growth of 3.4 per cent. After 1993/1994, the US inflation rate remained mostly under 3 per cent with one exception in 2005 when increase in fuel prices in the aftermath of two hurricanes drove up the inflation rate to 4.7 per cent. The unemployment rate also fell from a peak of 7.7 per cent in 1992 to 5.6 per cent in 1995 and further dropped to 4 per cent in 2000. Although the unemployment rate moved up in 2001-2003 to 6 per cent, the robust economic growth reduced the unemployment rate to below 5 per cent in $2005 .^{60}$

Japan, often considered an economic threat to the US in the 1980s and the early 1990s, fell into a prolonged recession in the 1990s. Asia's newly industrialised countries, especially Indonesia, Malaysia, and Thailand, were hit by the financial crisis in 1997-1998. Although China's economic growth remained strong in the 1990s, its mounting domestic economic and social problems deflated its economic challenge to the US. In the second part of the 1990s, the US 'new economy' driven by information technology not only restored economic and political confidence in the US, but also rebuilt the eroded US hegemony in the international system.

If US hegemony in the early 1990s was in decline, its economic revival boosted US hegemony in the middle of the 1990s. In 1990, US military spending constituted 29 per cent of total military expenditure in the world. After the post-Cold War defense budget cuts, US defense expenditures started to increase in absolute terms in 1996. In 2000, its proportion in world military spending rose to 43 per cent. After the September 11 terrorist attacks in 2001, President George W. Bush increased the defense budget dramatically. Consequently, US military spending reached 50 per cent of total military expenditure in the world in 2002 and was more than the combined spending of the next 15 countries after it. ${ }^{61}$ In 1998 ,

${ }^{60}$ Data from various issues of EIU Country Profile: The US (London: Economist Intelligent Union, 1995, 2000, and 2005).

${ }^{61}$ Stephen Brooks and William Wohlforth, 'American Primacy in Perspective', Foreign Affairs (July/August 2002), p. 21. 
the Department of Defense confidently claimed that 'the security environment between now and 2015 will [...] likely be marked by the absence of a "global peer competitor" able to challenge the US militarily around the world [...] The US is the world's only superpower today, it is expected to remain so through at least 2015. ${ }^{, 62}$

It is difficult to clearly identify when US policymakers changed the early uncertain (or temporary declining) hegemony perception to the later rising and stable hegemony. The change of perception is a gradual process rather than a momentary event. In addition, perception changes are not only based on the real power shifts, but also reflect policymakers' future expectations and predictions. US economy started to recover from recession in 1991 and its defense spending started to increase in 1996. Another defining moment for US hegemony is the 1997 economic crisis after which the so-called Asian Miracle became history and the US hegemony was re-confirmed. For the analytical purpose in this research, US policymakers' perceptions regarding US hegemony started to enter a new stage rising hegemony in 1995, gradually approaching stable hegemony in 2001.

As the power-perception hegemonic model suggests, US foreign policy towards Asia, therefore, also experienced a dramatic change from security-driven offshore balancing and multilateralism to power-oriented selective engagement and hegemonic dominion. In 1995, the US government announced that it would not further reduce its forward-deployed force in Asia and 100,000 military personnel would remain in the region. ${ }^{63}$ In 1996, the US and Japan issued the 'US-Japan Joint Declaration on Security', which reaffirmed the continued and growing importance of the US-Japan military alliance. In 1997, the revised 'US-Japan Defense Guidelines' were released by both governments. As Nye suggests, this treaty may be 'one of the most important policy developments for the region. It means that China cannot play a Japan card against the US, or try to expel the US from the region. ${ }^{64}$

Besides balancing China's rising military power, the revised US-Japan alliance also tightened US military and political control over Japan. Differing from offshore balancing, which suggests 'unleashing Japan' and leaving Asia, the selective engagement strategy reconfirmed US strategic intention to stay in the region. More importantly, the strengthened US-Japan alliance helped the US retain its hegemonic status in Asia. ${ }^{65}$ The US also tightened its bilateral alliance with South Korea and conducted military cooperation with Malaysia, the Philippines, Singapore, and Thailand. In the name of anti-terrorism, the US provided military assistance and started a military training program in the Philippines in 2002. Since the late 1990s, the US has been actively involved in many joint military exercises

62 William Cohen, Annual Report to the President and the Congress (Washington D.C.: Office of the Secretary of Defense, 1998), p. 3.

${ }^{63}$ US Department of Defense, United States Strategy for the East Asia-Pacific Region (Washington D.C., Department of Defense, 1995).

${ }^{64}$ Joseph Nye, 'China's Re-emergence and the Future of the Asia-Pacific', Survival: 39:4 (1997-1998), p. 77.

${ }^{65}$ For US hegemonic intention through the US-Japan alliance, see Mastanduno, 'Incomplete Hegemony and Security Order in the Asia-Pacific.' 
with its Asian allies, such as the annual Cobra Gold joint exercise in Southeast Asia. It is widely argued that, technically speaking, the US troops that withdrew from the region a decade ago have been back to Southeast Asia since 9/11. ${ }^{66}$

The evolution of US national security strategy from President Clinton to President George W. Bush also reflects the hegemonic trend of US foreign policy along with the rise of US power. After winning two regional wars in Bosnia and Kosovo with limited military assistance from its NATO allies and the international community, US unparalleled military power was empirically reconfirmed. In the 1998 National Security Strategy, President Clinton set the US strategic goal as to 'maintain the best-trained and best-led military force in the world' in order to ensure that 'US forces [...] have unchallenged superiority in the 21 st century.' It is a clear power-maximisation strategy, in which US policymakers believe that more power, rather than more security, is what the US wants in the international system.

After September 11 and the US military victory in Afghanistan, President Bush announced a more aggressive national strategy - a strategy of pre-emption. The US would use military force to prevent its rivals (including terrorist states) from acquiring potentially dangerous weapons that may pose threats to the US. Although the US calls it 'pre-emption', most critics suggest that this is indeed a preventive policy, which allows the US use force based on assumed threats rather than real threats. ${ }^{67}$ In December 2001, President Bush announced US withdrawal from the 1972 Anti-Ballistic Missile treaty (ABM) signed with Russia despite strong opposition from the international community (including close US allies). The abrogation of the ABM treaty paved the way for the US to deploy a National Missile Defense system in the US and Theater Missile Defense systems in Europe and Asia.

The perceptual boundary between rising hegemony and stable hegemony is clear in theory but vague in practice. The decade-long economic growth of the US slowed down in 2001. However, the power gap between the US and other great powers remains large. Given US economic and military primacy, US policymakers can ensure that no country can catch up with the US in next 20 years. Technically speaking, the US has entered the stable hegemony stage in 2001. However, the dynamics of the US economy may resume the momentum of US rising hegemony during stable hegemony, creating a temporary spike on the relatively stable trajectory of US hegemony.

On policy selections, selective engagement and hegemonic dominion are only different in degree but same in nature. While both policies are power-maximisation strategies for the hegemon, selective engagement can been seen as the early phase of hegemonic dominion. If the Clinton administration only conducted an aggressive selective engagement strategy to ensure US military primacy after 1995, Bush's 'pre-emption' policy after $9 / 11$ was close to hegemonic dominion in that the US

\footnotetext{
${ }^{66}$ Sheldon Simon, 'Southeast Asia and the US War on Terrorism', NBR Analysis, 13:4 (2002), pp. 25-40 and John Gershman, 'Is Southeast Asia the Second Front?'

${ }^{67}$ George W. Bush, The National Security Strategy of the United States (Washington D.C.: the White House, 2002). For criticism of the pre-emption strategy, see Walt, Taming American Power, p. 261.
} 
would not allow any adversaries to be even 'in hopes of surpassing, or equaling, the power of the US. ${ }^{, 68}$ More importantly, the US is willing to use force to stop any challenge if necessary.

The transformation of the US strategic goal from security to power along with the rise of US hegemony is also shown by the changing attitude and policy of the US toward multilateral institutions. As mentioned before, President Clinton set the APEC policy as the first priority during his first tenure in the White House. In addition, the US also participated in the ASEAN Regional Forum (ARF), a multilateral security institution initiated by the Southeast Asian states in 1994. Paralleling APEC, the US also emphasised the importance of ARF in regional security in the middle of the 1990s.

However, the US gradually lost its interest in both APEC and ARF in the late 1990s. After the Bogor Goals and Osaka Action, the development of APEC on economic liberalisation and cooperation became stagnant. The 1997 economic crisis in Southeast Asia also damaged the momentum of ARF in regional security. Although the inherent deficiency of Asian multilateralism, such as the lack of legalisation and institutionalisation, may be part of the reasons for the loss of US interest, the rising US hegemony also plays a significant role in distancing the US from multilateral institutions.

First, the recovery of the US economy in the mid-1990s reduced the urgency in promoting trade and pursuing economic security abroad through APEC. The broad application of communication and information technology revitalised the US sluggish economy in the mid-1990s. The US government budget deficits started to end in 1998 and the unemployment and inflation rates fell. Economists started to debate the US 'new economy' and ask how the US could make a surprising upturn after a serious recession in the early 1990s, while other industrialised economies such as Japan and the European countries either faced prolonged recession or experienced stagnation. More importantly, the domestic economic recovery boosted US confidence in foreign affairs, and its policy became more assertive and unilateral. Consequently, the US original interests in relying on the APEC to boost its domestic economy were also waning along with the boom of the US 'new economy'.

Second, the US attitude toward ARF also experienced a downturn in the late 1990s mainly because of the 1997 economic crisis. Although the crisis ended the Asian Miracle, it did not have a significant impact on the US economy. On the contrary, the US domestic economy still maintained healthy growth in the late 1990s. The end of the Asian miracle not only boosted US confidence in sustaining its hegemony in the region, but also increased the leverage of the US in dealing with challenges from Asia. Although multilateralism was still officially endorsed by the US government in the late 1990s, no real actions followed the rhetoric. ${ }^{69}$ If the US had hoped to shape the development of ARF after it joined in 1994, this hope was abandoned after the Asian economic crisis. More importantly, the US lost its patience and interest in the ARF 'talk shop' after further reconfirming its rising hegemony following the economic crisis.

${ }^{68}$ Bush, The National Security Strategy of the United States, p. 30.

${ }^{69}$ Evelyn Goh, 'The ASEAN Regional Forum in United States East Asian Strategy', The Pacific Review, 17:1 (2004), p. 55; see also William Tow, Asia-Pacific Strategic Relations: Seeking Convergent Security (New York: Cambridge University Press, 2001). 
Interestingly, however, after the September 11 tragedies the US began to resume its interest in the APEC and ARF. In the 2001 Shanghai APEC meeting, the US initiated the anti-terrorism topic in the leaders' summit, and APEC leaders issued the first political issue-related statement, 'Leaders' Statement on Counterterrorism', to support the US global campaign against terrorism. Since then, anti-terrorism has become a major topic of APEC, which was originally an economic institution. In addition, the US also successfully used ARF as a platform to expand its global campaign against terrorism, and anti-terrorist cooperation became one of the top issues discussed in recent ARF meetings. This resurgence of US interest in multilateralism is due to two possible reasons.

First, the terrorist attacks might have slightly changed US leaders' perceptions regarding US hegemony. Although no country can even possibly threaten US security by traditional means, the terrorist attacks reveal the vulnerability of US hegemony. It is not certain whether terrorist attacks indeed signify a decline of US hegemony. But terrorism at least makes US policymakers realise the limitation of US military power. Therefore, multilateral institutions become a useful tool for the US to pool political support around the globe, even if just rhetorically.

Second, although the US resumed its interests in ARF and APEC during its war on terror, it is hard to argue that the US had changed its power-maximisation policy, that is, from selective engagement and hegemonic dominion to multilateralism. Instead, it reflected how the US used its preponderant power to press other states for its own interests. For example, APEC was designed to be an economic forum. China and other ASEAN states tried hard to resist any attempt by Western states, especially the US, to insert political and security agendas into APEC in the 1990s. However, this non-security taboo was eventually broken by the US after 9/11. Under US pressure, more political and security agendas have been injected into APEC. However, it is still not clear how the US will play the APEC card in particular or multilateral institutions in general because the US intentionally ignores the ASEAN Plus Three and East Asia Summit; the other two important multilateral institutions in the Asia-Pacific. Compared to US military actions, both APEC and ARF played a minor role in the US strategy against terror. In other words, the function of APEC and ARF may be just a political or moral cover for the US global dominion strategy.

\section{Conclusion}

Rather than debating which strategy is best for the US under unipolarity, the more relevant question is to examine which foreign policy is more likely to be adopted by US policymakers under the different stages of US hegemony. Four prevailing strategies, hegemonic dominion, selective engagement, offshore-balancing, and multilateralism, are all on the table for US policymakers. How US policymakers select from them depends on how US hegemony is perceived.

When US policymakers perceive a rising or a stable hegemony, the anarchic nature of the international system is no longer valid in the mind of US policymakers because the preponderant power makes the US immune from military threats. In the self-perceived, hierarchic international system with the US 
on the top, power-maximisation becomes the strategic goal of the US in part because of the 'lust for power' driven by human nature and in part because of the disappearance of the security constraints imposed by anarchy. Therefore, selective engagement and hegemonic dominion become two possible strategies for the US to maximise its power in the world. The larger the power gap between the US and others, the more likely selective engagement expands to hegemonic dominion.

When US policymakers perceive a declining hegemony in that the power gap between the hegemon and others is narrowed rather than widened, US policymakers begin to change their hierarchic view of the international system. The rapid decline of relative power causes US policymakers to worry about security imposed by anarchy even though the US may remain the most powerful state in the system during the process of decline. Offshore balancing and multilateralism, therefore, become two possible policy options for the US to maximise its security under anarchy. The possible budget constraints during US decline may lead to military withdrawals from overseas bases. In addition, the US becomes more willing to pay the initial 'lock-in' price of multilateral institutions in order to constrain other states' behaviour for its own security.

US foreign policy towards Asia preliminarily supports the power-perception hegemonic model. When President George H. W. Bush came to power, the US faced 'dual deficits' even though the US won the Cold War and became the hegemon by default in the early 1990s. The domestic economic difficulty imposed a declining, or at least uncertain, hegemony to the Bush administration. Consequently, Bush had to withdraw troops from Asia and conducted a reluctant offshore balancing strategy in the early 1990s. Although the US still claimed to keep its commitments to Asian allies, the US words with the sword became unreliable at best.

During President Clinton's first tenure, how to revive US economy became the first priority of the administration. The perception of a declining hegemon did not totally fade until the middle of the 1990s when the US economy gradually came out of the recession. Multilateral institutions, especially APEC, became Clinton's diplomatic weapon to open Asia's market and boost US economy. In addition, the US also endorsed the ARF initiated by the ASEAN states in order to retain its eroding political and military influence after the strategic retreats in the early 1990s.

However, the US 'new economy' based on information technology and computers revived policymakers' confidence in US hegemony after the Asian miracle was terminated by the 1997 economic crisis. The second part of the 1990s witnessed a rising US hegemony and the George W. Bush administration reached the apex of US power by any measure in the early 21 st century. Therefore, since Clinton's second tenure in the White House, US foreign policy in general and towards Asia in particular has become more assertive and power-driven in nature. Besides reconfirming its traditional military alliances in Asia, the US deepened its military engagement in the region through extensive security cooperation with other Asian states.

The selective engagement policy of the US in the late 1990s was substantially expanded by the Bush administration to hegemonic dominion after 9/11. The unrivalled hegemony relieved US of concerns over security threats from any other states in the international system. The 'lust for power' without constraints from 
anarchy drove US policymakers to pursue a hegemonic dominion policy in the world. The 'pre-emption strategy' and proactive missile defence programs reflected the power-maximising nature of the hegemonic dominion strategy during the George W. Bush administration.

What will the US do in the future? The power-perception hegemonic model suggests that the US cannot escape the fate of other great powers in history. When US hegemony is still rising or at a stable stage, no one can stop US expansion for more power. When its economy can no longer afford its power-oriented strategy, the US will face the same strategic burden of 'imperial overstretch' that Great Britain suffered in the 19th century. However, the power-perception hegemonic model also argues that US foreign policy depends on how US policymakers perceive the rise and fall of US hegemony.

If historical learning can help US policymakers cultivate a prudent perception regarding US hegemony, the early implementation of offshore balancing and multilateralism may facilitate the soft-landing of declining US hegemony. More importantly, the real danger is whether the US can make a right choice between power and security when US hegemony begins to decline. If US policymakers cannot learn from history but insist on seeking more power instead of security even though US hegemony is in decline, the likelihood of hegemonic war will increase. However, if US policymakers choose security over power when US hegemony is in decline, offshore balancing and multilateralism can help the US maximise security in the future anarchic, multipolar world. 